\title{
ENGLISH BILINGUAL EDUCATION: THE \\ CHALLENGE OF COMMUNICATION AND \\ COGNITION ASPECTS OF CONTENT LANGUAGE \\ INTEGRATED LEARNING (CLIL) IN INDONESIA
}

\author{
Astri Hapsari \\ Islamic University of Indonesia
}

\begin{abstract}
This essay analyses the challenge of the implementation of Content Language Integrated Learning (CLIL) in the curriculum framework in Indonesia. Review on related literature and research findings support the arguments that the implementation of CLIL brings about the issues in cognition and communication aspects. Unless more appropriate English language education and more educational linguistic research are established, the implementation of CLIL should be reconsidered.
\end{abstract}

Key words: English bilingual education, CLIL, Indonesia

\section{INTRODUCTION}

In current society, English has reached the status of global language. Three main pillars that support the current status of English are "population, position, and prestige" (Ostler, 2006). English is used as an official language by seventy-five countries with a total population of over two billion (Crystal as cited in Graddol, 2000). In addition, there are 375 million people using English as a native language while 375 million speakers use it as their second language and approximately 750 million people are using English as a foreign language (Crystal as cited in Graddol, 2000). The global coverage of English is also well-supported by close relationship among English, technical progress and popular culture in the world (Ostler, 2006). Moreover, Bourdieu's (1997) arguments on his cultural capital thesis, justify the reason why people decide to learn English. In Bourdieu's (1997) terms, students who have "habitus" (cultural background) and "dispositions" (motivation, family support, social advantage, positive attitude to school, high culture, etc.) will be 
more successful than the students who do not have these factors. Since English has an established sociocultural status in the world, it is believed that English will help the students to acquire a "high culture" so that they will have better opportunity in academic achievement and better social status in the society. As a result, learning English is considered as a cultural capital and English bilingual education is widely developed around the world.

Content Language Integrated Learning (CLIL) is an approach in second or foreign language teaching established in bilingual education projects. Inspired by the success of immersion English-French bilingual program in Canada, European countries have developed CLIL to fulfill the demand to educate multicultural and multilingual citizens (Lasagabaster, 2008). This approach is seen as an innovative approach because it integrates linguistic demands of language and content subject. Moreover, it also promotes problem solving and higher order thinking abilities (Coyle, Hood, \& Marsh, 2010, p.14). CLIL gives some benefits in promoting second language learners' language ability. A study conducted in a German context reveals the advantages of language learning by using CLIL, as students attain better foreign language competences, such as: receptive skills, vocabulary, fluency, writing and pronunciation, than those enroll in regular course (DaltonPuffer, 2007 as cited in Lasagabaster, 2008). Research conducted in the Basque Country whose official languages are Spain and Basque also gives the evidence about "the effectiveness of CLIL even in a bilingual context where the foreign language concerned (English) is hardly used outside the school setting" (Lasagabaster, 2008). These research findings bring about the belief that CLIL should be implemented not only in European countries but also Asian countries in order to improve the quality of bilingual education.

\section{ENGLISH BILINGUAL EDUCATION AND CLIL IN INDONESIA}

In Indonesia, English bilingual education projects started to emerge with the establishment of 2003 Act No 20 of the National Education System chapter XIV, article 50 (3) which states " The central government and or the local government establishes at least one unit in each educational level to be developed as an international standard class". Following the government act, research about the use of English in teaching science and mathematics were conducted in 2004 and several pilot schools, called International Standard School (Sekolah Bertaraf 
Internasional/ SBI), were established (Bax, 2010). Supported by The Minister of National Education decrees No 23/2006, which states that international standard class should be based on ICT assisted learning and English is used as language of instruction for math and science, an international class is established in every SBI, These laws are established on the ground of cultural capital belief and the global market issues which urge people to increase their competitive values by mastering the subjects such as science, math, and IT in English. In order to promote the bilingual education program, the elements of CLIL are implemented into school curricula.

Despite the support from government policy, the problem faced in implementing CLIL in Indonesia deals with the unprepared teaching staff who deliver the content subject in English (Zaenuri, 2007; Fatmawati, 2011; Perkasa, 2011). Another problem arises considering the status of English as a foreign language (EFL) in Indonesia. The official language in Indonesia is Bahasa Indonesia (Indonesian) which has been declared as a lingua franca of Indonesia in 1928 Youth Pledge, far before the declaration of independence in 1945. On the other hand, people in Indonesia use their regional language for daily conversation. Therefore, before the establishment of 2003 Act No 20, English only has a place as a subject in curriculum and is not widely practiced in the society. As a result the implementation of CLIL faces challenges in communication and cognition aspects. From the description of the problem, I will use evidences to argue that the implementation of CLIL in English bilingual education in Indonesia will be successful if: first, the teachers, who deliver the content subject in English, has appropriate level of basic interpersonal communicative skills (BICS) and cognitive/academic language proficiency (CALP); second, the curriculum is designed by considering "the instructional implications of CALP" (Baker, 2011, p.172).

\section{BASIC INTERPERSONAL COMMUNICATIVE SKILLS (BICS) AND COGNITIVE/ ACADEMIC LANGUAGE PROFICIENCY (CALP) IN CLIL}

The terms of BICS and CALP are introduced by Cummins (1979, as cited in Baker, 2011). BICS occurs when "there are contextual supports and props for language delivery", such as: "face-to face context embedded situations" which 
provide" non-verbal support to secure understanding" (Baker, 2011, p.170), while CALP occurs in "context reduced academic situations" (Baker, 2011, p.170). Halliday \& Hasan (1985), as cited in Butt, Fahey, et. Al (2003), mention that the language use is influenced by the context of culture and situation. Moreover, they point out that the contextual factors of situation are influenced by field (the topic of the text), tenor (speakers and listener, or writer and reader's relationship), and mode (communication channel). These three variables make up what is referred to as register. People who are proficient in a language develop the ability to vary the register. In line with BICS and CALP introduced by Cummins, people who learn a second language should also develop this ability in order to communicate the meaning intended properly. However, since the register in CALP is contextreduced, it necessities the speaker to have both higher level language proficiency and register mastery.

Indonesian teachers who use English as their language of instruction in the classroom have to have both appropriate language proficiency and register mastery in order to deliver the content of the subject properly. For example: a teacher who teach mathematics in English has to have the mastery in "language of learning" (such as: adjacent, column), "language for learning" (such as: divide, times, estimate), and "language through learning" (the language to negotiate the meaning in learning process, such as: share, altogether, join) (Coyle, Hood,\& Marsh, 2010, p.36). The problem arises because teachers who are not native speakers of English often face difficulties because they are not familiar with both language of the content and language used to negotiate meaning. In his research for British Council, Bax (2010) emphasis that "even though the English used in the observed lesson was communicative...it did suffer from some inaccuracies". This findings is related to how English was learned when the teachers were still students. Most teachers in Indonesia learn English in English as a Foreign Language (EFL) context when they were students, so it is impossible to have an appropriate BICS and CALP if they only attend short-term trainings. From his research to immigrant students in Canada, Cummins (1979, as cited in Baker, 2011) found that it takes at least two years to master everyday conversational language while it could take five to seven years to develop the more advanced language abilities to deal with the curriculum. The question is how can the cognition aspect of CLIL, which in ideal condition should involve "problem solving and higher order thinking" (Coyle et al., 2010, p.14) be achieved, if the teachers are not qualified in integrating the 
content and language? Thus, I shall argue that the implementation of CLIL would be a failure if teachers did not possess appropriate BICS and CALP to teach the subject matters.

Moreover, the instructional implication of CALP must be considered in order to implement CLIL successfully. Cummins (1981, as cited in Baker, 2011) points out this implication in two- dimension diagram model with four quadrants which considers BICS as context embedded and cognitively undemanding communication while CALP as context reduced and cognitively demanding communication. These instructional implications include: planning tasks, teaching strategy and assessment.

In Indonesia, the tasks are often adapted from the materials which are based on Singaporean, Australian, or Cambridge curriculum (Gower, 2002). In adapting the material, teachers often forget that the students in Indonesia are in different context in the exposure of English from the students in Singapore or Australia. The students in Singapore or Australia, where Cambridge curriculum is intended to be designed, use English as their first or second language. These students must have better mastery of BICS and CALP than Indonesian students. In contrast, English is used as a foreign language in Indonesia where students are not exposed in English as much as the students in Singapore and Australia do. As a result, most students in Indonesia find the tasks are not affordable. They have too much cognitive input from language and content without developing the abilities to link the content and language. Gajo (2007) argues that the idea of integration language and content should give the priority either to linguistic issues or to subject issues according to the task/ sequence being carried out, even if discourse remains the common entrance to both (p.578)

As a consequence, planning task and teaching strategy for a CLIL lesson requires discourse analysis study so that the students can have authentification (Gajo, 2007) of the content. In addition, teachers should develop techniques in adapting the materials such as addition, expansion, deletion, subtraction, reduction, modification, replacement, reorganization, resequencing, and conversion (Tomlinson \& Hitomi, 2004) by considering the students' English proficiency.

Another issue is that the assessments in international standard class are still in Indonesian (Zaenuri, 2007 ; Bax, 2010). It creates the mismatching between 
what the students have learned in the classrooms, in which English is used as the language of instruction, with what is examined in the assessment. As a result, it will create confusion about how to present their cognitive input in different discourse competence. Gibbons (2001, p.52) points out that ESL students have a problem in writing because "trying to grasp concepts...is obviously much more difficult in a language in which you are not strong". In short, I argue that to have a benefit from English bilingual education, the curriculum should be carefully arranged by considering the local context where CLIL is implemented. Adapting curriculum from abroad without considering the affordance of the students and appropriate teacher's training will lead to failure in developing the students' CALP. It will make the students feel more confused about the content rather than develop their higher order of thinking and problem solving ability.

\section{THE IMPLICATIONS OF BICS AND CALP IN THE IMPLEMENTATION OF CLIL IN INDONESIA}

There are three implications of these BICS and CALP issues on the implementation of CLIL in Indonesia in order to have a successful English bilingual education: first, the need to recruit native speakers with content-specific qualification with Teaching English for Speakers of Other Languages/ TESOL qualification to teach educational students specialized in science, mathematics, and IT subjects in the universities, or to facilitate educational students majoring in science, mathematics, and IT subjects to study abroad; second, the importance of developing a standardized certification to measure teachers' CALP ; and finally, the need to do more educational linguistics research in Indonesia context.

Educational students in undergraduate level who are prepared to be teachers spend four years to complete their course. If they are immersed in English taught by native speaker instructors with content mastery and appropriate TESOL qualification, they will accomplish an appropriate level of BICS and CALP of the content subjects. Another option is by facilitating these students to study abroad in the universities which use English as language of instruction, so that they experience English in the real society. The government should also develop a standardized certification to measure teachers' BICS and CALP. In the future, teachers who do not fulfill appropriate level of BICS and CALP in English should not teach international standard class. 
And the last, educational linguistics research must be developed to find out the level of affordance of students to English. Even if "the competitiveness in global market" somewhat becomes the reason to learn English, I still doubt whether it is necessary to integrate it with the content, if it makes the students fail to understand the concept because they are unable to express themselves in the language that is more familiar and widely spoken in their daily life. In Basque context, CLIL is successful because it is implemented in learning context where both majority (Spanish as L1) and minority (Basque as L1) language students share the same class. In addition, English is more accessible due to the mobilization of people across Europe. On the other hand, Indonesia has more than 300 native languages (or regional language) and use English in EFL context. In most regions in Indonesia , the students are diverse in cultural background and use their regional language as L1 (minority language) in daily conversation, while in the CLIL class they use Indonesian (majority language) to learn most content subject, and English as L2 (majority language) to learn mathematics, science, and English. Most of the students have already had problems to understand the lesson in Indonesian because their regional language's logical patterns are different from Indonesian's; and, at the same time, they also have to deal with English. As a result, some students may feel overwhelmed with the languages and fail to comprehend the content. In such cases, I believe, it will be better to implement CLIL only in English as a Foreign Language subject.

\section{CONCLUSIONS}

From the previous discussions, CLIL is believed to be an innovative approach which integrates language and content. It gives advantages to develop higher order thinking and problem solving ability which add students' competitive values in the global market. On the other hand, the issues of BICS and CALP of the teachers prove that the implementation of CLIL in Indonesia must be reconsidered, because evidence shows that most students cannot understand the subject content properly. However, English is the language which has global coverage. Therefore, CLIL should be sustained by providing appropriate English bilingual education for the teachers who are going to teach in international standard classes and doing educational linguistic research which examines the level of students' affordance to English. 


\section{REFERENCES}

Baker, C. (2011). Foundations of Bilingual Education and Bilingualism. Buffalo, New York: Multilingual Matters.

Bax, S. (2010). Researching English Bilingual Education in Thailand, Indonesia, and South Korea. In Phillip Powell-Davies (Ed.). Malaysia: British Council.

Bourdieu, P. (1997). The forms of capital. In A.H. Hasley, H. Lauder, P.Brown, and A.S. Wells (Eds.). Education: culture, economy, and society. Oxford: Oxford University Press. 40-58.

Butt, D., Fahey, R., et. Al (2003). Using Functional Grammar: An Explorer's Guide. Sydney: National Centre of English Language Teaching and Research.

Coyle, D., Hood, P., \& Marsh, D. (2010). CLIL : Content and Language Integrated Learning. New York: Cambridge University Press.

Fatmawati. (2011). Teaching Mathematics Using Two Languages. Retrieved on November 1,2011, from http://lovewatergirl.wordpress.com/2011/01/21/

Gajo, L. (2007).Linguistic knowledge and subject knowledge: how does bilingualism contribute to subject development? The International Journal of Bilingual Education and Bilingualism, 10(5), 563-580.

Gibbons, P. (2001). Writing in a second language across curriculum: an integrated approach. In P. Gibbons (Ed.). Scaffolding Language Scaffolding Learning. Portsmouth: Heinemann.51-76.

Gower, S. (2002, January 7). Bilingual Education Remains a Fantasy for Indonesian School. The Jakarta Post. Retrieved on November 1, 2011, from http://www.thejakartapost.com/news/2002/07/01/.

Graddol, D. (2000). The Future of English? A Guide to Forecasting the Popularity of the English Language in $21^{s t}$ century. United kingdom: The British Council, 10-11

Lasagabaster, D. (2008). Foreign Language Competence in Content and Language Integrated courses. The Open Applied Linguistics Journal, 1,31-42. 
Ostler, N. (2006). Empires of the Word: a Language History of the World. London: Harper Perennial.

Perkasa, V. (2011, July 30). In Search of Innovative Teaching, Learning Practices. The Jakarta Post. Retrieved on November 1, 2011 from http://www.csis.or.id/Publications-OpinionsDetail.php?id=836.

Republic of Indonesia. Act of the Republic of Indonesia Number 20, Year 2003 on National Education System, Chapter XIV article 50 (3). Retrieved on October, 252011 from http://planipolis.iiep.unesco.org /upload/Indonesia/Indonesia Education Act.pdf.

Republic of Indonesia .The Minister of National Education Decrees No.23/2006. Retrieved on October 25, 2011 from www.vnseameo.org /downloads/malay/Indonesia.doc.

Tomlinson, B., \& Matsura, H. (2004). Developing Language Course Materials. Singapore: SEAMEO Regional Language Center.

Zaenuri, M., (2007). The Implementation of SMP SBI in SMPN 1 Kota Mojokerto : a case study. Retrieved on October, 282011 from http://www.scribd.com/doc/7034770/. 